\title{
Translation as Facilitator of Social Movements in Late Qing China: A Skopos Theory Perspective
}

\author{
Qing Liang Meng $1,2, *$ \\ ${ }^{1}$ Jia Xing University, Jiaxing, 314200 ZHJ, China \\ ${ }^{2}$ University College Dublin, Dublin 14, Ireland \\ *Correspondence: E-mail: qing.meng@ucdconnect.ie
}

Received: November 5, 2018 Accepted: December 6, 2018 Online Published: January 7, 2019

doi:10.5430/sass.v6n1p1 URL: https://doi.org/10.5430/sass.v6n1p1

\begin{abstract}
Unlike the previous two translation waves in the history of China, the third translation wave beginning from Late Qing period can be seen as a cross-cultural communication under confrontation and conflict between China and western powers. Missionaries and government officials from western powers, institutions affiliated to government, and social activists were actively engaged in various translation activities for their respective purposes by means of cooperation, which had not only promoted western learning in China and facilitated Chinese social movements and reform, but finally brought the Qing Dynasty to an end in the Chinese Revolution of 1911. This paper aims to explore the facilitating role of translation in social movements and reforms in China during the time of the Late Qing Dynasty from Skopos Theory Perspective, in order to show that translators as social activists can not only promote intercultural communication, but also push forward social changes and help nation building. This translation wave is characterized by urgency, purposefulness and practicality, and played the role of enlightening people, spreading western learning and facilitating revolution.
\end{abstract}

Keywords: Skopos theory, Late Qing Dynasty, China, translation, reform, facilitator

\section{Introduction}

The Skopos theory is proposed by German translation researcher Hans J. Vermeer in the late 1970s. Skopos is a Greek word meaning "purpose." As a translation theory, it holds that any form of translation, including translation itself, is an action. And any action has its goal or purpose, which leads to a new event or situation. As implementers of translation actions, translators perform translation tasks on their own initiative or at the request of others. Moreover, as experts in the field of translation, translators can decide for themselves what role the source text should play in their translation (Vermeer, 2000). Pym believes that the Skopos principle means that translators make decisions based on the requirements of commissioners, who as the "end-users"of products; and on the other hand, by "what the translator thinks the purpose should be" (Pym, 2014: 44). Nord lists Skopos as one of the four functional translation theories (Nord, 2002). Based on this theory, translation is directly defined as a purposeful action, and from the theory of action, translating is regarded as a form of translational, intentional and interpersonal interaction involving communicative, intercultural, and text-processing action (Nord, 2014).

In addition, according to Skopos theory, the source text is a description of a certain situation embedded in the source language culture, and the translation process is an intercultural communication. The translator's translating is either deliberate or entrusted by others. The entrustment of the task usually or should cover: objectives and conditions such as deadlines and fees. The Skopos of the translation activity is the target or purpose determined by the commissioning party, and is appropriately adjusted by the translator.

This article is an attempt of the author to explain the reason, organization, purpose and content of the translation activities during the Late Qing Dynasty of China by means of Skopos theory, with the view to exploring the translation methods or strategies adopted, and the role of translation works in motivating and facilitating social movements and transformation at that time. 


\section{Overall Situation of Late Qing Dynasty}

Around 1840 A.D., China was the largest country in the world in both area and population. The United Kingdom launched the first Opium War to China the huge market to expand its commercial landscape, forcing the Qing government to sign the"Nanjing Treaty"with the result of marching northward to the capital along the Chinese coast. Subsequently, other Western powers also followed suit, using hardships to force Qing government to sign similar unequal treaties and open trade ports. After the Second Opium War of 1856, the Qing government signed the "Tianjin Treaty", the "Beijing Treaty" and the "Sino-Russian Treaty of Aihui"with Britain, France and Russia respectively. Then the Qing government continued to cut land and pay reparations following the defeat in the Sino-French War of 1884, Sino-Japanese War of 1894. Signing unequal treaties with western powers without completely losing the resistance force exposed the corruption and inefficiency of the Qing government and consequently undermined the basis for its rule. On the other hand, the new type of trade brought about by the trading ports has undermined the traditional rural economy, while the increasingly heavy taxes made things worse, giving rise to the deep hatred and uprisings from the vast majority of people. A popular proverb was circulated in the south of the Yangtze River that "People are afraid of bureaucrats, bureaucrats are afraid of foreigners, foreigners are afraid of the people" (Chesneaux, Bastid, Bergere, \& Destenay, 1977: 87-88). In 1851, Hong Xiuquan rebelled in Jintian, and the following Taiping Heavenly Kingdom Movement under his leadership spread to a dozen provinces lasting for more than a decade. Even though he failed in the end, the movement inflicted fatal strike to the rule of Qing government.

Under the interweaving of multiple factors such as wars, civil strife, corruption, and famine, people from various classes of society have become increasingly dissatisfied with the Qing government. After the 1860 s in particular, there had been louder and stronger call for self-reliance. In this dilemma of internal and external troubles, the Qing government itself, on the one hand, has also made efforts to reform itself with the advocacy of the reformists, in the hope of reversing the adverse trend and thus launched a massive and far-reaching Westernization movement. On the other hand, people from all walks of life have also initiated social reforms one after another out of their loyalty to the nation and a sense of mission, from the road-protection campaign to the Reform Movement of 1898, until the Revolution of 1911 which once and for all overthrew the Qing Dynasty and established the Republic of China.

\section{Translation Activities during Late Qing Dynasty from Skopos Perspective}

From the Skopos theory perspective, translation as a social behavior has its specific purpose, for which the translator chooses appropriate source language texts and adopts corresponding methods or strategies, so that the final product, namely the target language text, can achieve the purpose of changing the situation or generating new things.

In the late Qing Dynasty, three main bodies were actively engaged in translation activities for their own purposes or objectives: (1) Western government officials and missionaries; (2) Official institutions of the Qing government; (3) Civil institutions or social activists.

\subsection{Translation Activities of Missionaries and Officials of Western Governments}

After the American Revolutionary War, the British lost the American colonies and turned to South Asia and Southeast Asia, regarding China as the most crucial market. However, due to the growing sense that the Qing government has become an obstacle to business and missionary causes, "English politicians, merchants, and evangelicals articulated through religion and science their goal of opening China to the international community of nations and enlightening its peoples (Elman, 2005: 283)". Of course, their real purpose is to exploit resources from this huge market. To this end, the United Kingdom established the London Missionaries Association (1795), the British Overseas Missionary Association (1799), while the United States formed the Salvation Army and the Sunday School. European countries also had various Catholic missionary communities in China. As early as several decades before the Opium War, these institutions were already gearing up for activities in Guangzhou and Macau. At the end of 1834, the missionary-businessmen association formed the "Society for the Diffusion of Useful Knowledge in China", with the name itself indicating the purpose of the association. Given that many of the major physical and chemical discoveries in the 18th century were almost unheard of at the time in China (Wright, 1998: 658), the association launched an ambitious plan three years later to translate twenty-four books of different disciplines into Chinese, including history, geography, nature, and medicine, mechanics, natural theology. According to Elmer, in 1840, about 20 missionaries from several European countries were stationed in China (Elman, 2005: 285).

In 1842, the British missionaries moved the London Missionary Press from Hong Kong to Shanghai and renamed it the Inkstone Press. After Alexander Wylie took over in 1847, this agency became the publishing center of the 
missionaries. Like other missionary agencies, the main purpose during the initial stage of the establishment of the Inkstone Press was to "promote the gospel," and thus "mainly engaged in translating and printing the Bible and other religious books" (Liu \& Lan, 2015). However, due to the resistance from domestic intellectuals, such missionary methods did not achieve the desired results. In order to eliminate the hostile attitudes of the people in the country, the Inkstone Press changed its strategy to practically disseminate practical scientific knowledge in order to gain the trust of the Chinese and pave the way for further missionary activities.

By the 1850s, foreign missionaries working in Inkstone Press had included Wylie, J. Edkins, A. Williamson, and others. They translated some books in mathematics, astronomy, physics, plants and medicine with the assistance of their "remarkably intelligent" Chinese colleagues. In 1851, D.J. Macgowan published "The Book of Nature", and in 1854 B. Hobson published the "A New Compilation on Natural Philosophy: First collection" in Guangzhou. By the $1880 \mathrm{~s}$, the missionary groups had successively established agents to supervise translation activities and a standardization committee was designated to negotiate the definitions of scientific and technical terminology (Wright, 1998: 660).

\subsection{Translation Activities of Qing Government Agencies}

Although the missionaries carried out a large number of translation activities, systematic and large-scale scientific translations were completed by the Qing government at that time. On the eve of the Opium War, Lin Zexu went to Guangzhou to ban opium and "acquire information on the 'Alien States"' (He, 2001). He particularly encouraged the collection, translation and study of Western countries, ranging from missionary manuals, business agreements, and geographical overviews (Chesneaux, Bastid, Bergère, \& Destenay, 1977: 74) so as to "be well-informed of self and opponent" when negotiating with the British. Entrusted by Lin Zexu, Yuan Dehui together with the American missionary Peter Parker translated some chapters of the "Elements of International Law" by Swiss international jurist E. De Vattel (1714-1767) into Chinese. However, as the result of the failure of the Opium War, Lin Zexu was dismissed and investigated and the work was terminated. It was not until the 1860 s that the book was completely translated into Chinese by William Martin with the support of the American emissary. After being revised by the Ministry of Foreign States Affairs, the book was published and published by Chongshi Press, thus "transplanting Western international law into China, which has had a huge impact on Chinese legal community" (He, 2001).

In the mid-nineteenth century, several western aggressive wars against China caused hostile attitude among Chinese people towards Western culture, but some officials known for their "self-improvement" belief advocated learning western science and technology, especially military knowledge, to fight against their cannons, which is called "Barbarian skills to barbarians". Despite being opposed by the conservatives, the Qing government established the Imperial Tongwenguan in 1862 under the support of the reformists like Yixin, followed by the establishment of Jiangnan Arsenal, Anqing Arsenal, and Fujian Arsenal Academy in 1865, with scholars from both China and western countries working together to translate Western works on science and technology. In 1870, the Translation Departments of Shanghai Tongwenguan and Jiangnan Arsenal were merged as one institution, employing John Fryer (1839-1928) as the director. In the following thirty years, "The total of Fryer's contributions at the arsenal came to 129 translations, with 77 being published at the arsenal" (Elman, 2005: 362). The translation department has become China's most important agency in translating scientific and technological literature, and with special focus on Western military books. This is also in line with the idea of Zeng Guofan, one of the leaders of the Westernization Movement who hopes that the Jiangnan Arsenal "would play a leading role in restoring the power of the dynasty" (Wright, 1998: 662). In fact, the translation activities of Jiangnan Arsenal are "very brilliant, with translation quantity and quality far exceeding those of Imperial Tongwenguan and The Christian Literature Society for China of the same period" (Zhang, 2010).

Under the guidance of the "self-improvement" concept of the reformists, the source texts selected by the translation department are mostly directly related to machine manufacturing and this is determined by purposeful activity of translation. In order to design and produce steam engines, Wylie and $\mathrm{Xu}$ Shou co-translated the Steam Engine Manual, which was published by the Jiangnan Arsenal in 1871. In the specific translation activities, the translators of Jiangnan Arsenal adopted the Buddhist translation strategy, that is, the foreigners with a certain level of Chinese language first explained the main points, which were then written down in Chinese by native Chinese interpreters after polishing. This is a very difficult job in that the foreigners who are limited by the level of Chinese language may not always be able to tell clearly what the source texts are about, requiring Chinese interpreters not only to have a thorough understanding of the professional knowledge involved, but also have to guess, conjecture and make decisions before expressing the meaning fluently and elegantly. In this way, mathematician Hua Yifang translated J.D. Dana's Handbook of Mineralogy and C. Lyell's Geological Foundation and other works in cooperation with 
McGowan. When talking about the translation of these scientific works, Fryer said, "Nothing but a strong sense of duty and a firm belief that this kind of labor is one of the most effective means, under the Divine Guidance, for bringing about the intellectual and moral regeneration of this great country"(Wright, 1998: 664).

\subsection{Translation Activities of Civil Agencies or Social Activists}

In addition to official translation agencies established by western governments or missionary agencies or by the Qing government, a few other translation or printing institutions, the most important one of which should be the Commercial Press, have also been set up by civil intellectuals or social activists who realized the importance of cultural transmission and Western learning in the social turmoil and radical changes. In 1897, Xia Ruifang and a few others who graduated from a church school and worked in the American Presbyterian Mission Press, raised funds with the help of the American priest George F. Fitch and set up the Commercial Press. Since its founding, the Commercial Press had introduced and translated "Initial Textbook for English-learning" and "Advanced Textbook for English-learning" in response to the upsurge of learning English and achieved great success. In the following years, the Press increased investment and expanded its scale. After Zhang Yuanji was employed as the director of the translation and compilation office, he considered the situation and strongly supported translation activities in line with the "western trend under which people are eager to look at Europe and the United States for new knowledge to change the country's deteriorating situation" (Chen, 2017). The publication of Yan Fu's translation of "Evolution of Species" and Lin Shu's translation of "La Traviata de Paris" were published in 1903 and achieved another great success. Afterwards, the Press successively launched a series of Chinese translations of Western masterpieces and had exerted profound influence on Chinese society in terms of reforms, translation, western learning, enlightenment ideas, and promotion of progress. In addition, the Datong Translation House established by Liang Qichao and others in Shanghai, translated and published "Swiss Legal Reform," "Russian Civil War," "Japanese Book Catalogue," "Chinese and Western Studies," and "XinxueWeijingKao," "The Italian Chivalrous Biography," and the "Da Tong He Bang Xin Yi”.

Yan Fu (1853-1921) was firstly enrolled at the Fujian Arsenal Academy before going to study in the UK. After completing his studies abroad, he returned to teach at the Academy. Deeply affected by the fierce defeat of China during the Sino-Japanese War, he began writing and advocating learning from the West for reform and self-improvement. At the same time, he used his own language advantages and his experience in studying abroad to translate works in such disciplines as politics, economy, philosophy, logic and legal science that can help people's enlightenment and understanding of nature and society for the purpose of making China "self-reliant, independent, and progressive". In translating Huxley's Evolution and Ethics, he intentionally adopted domestication strategies in converting such key concepts as "natural selection", "survival of the fittest" into brand-new Chinese idioms, which, after being reproduced and disseminated through newspaper articles, had, on the one hand, greatly penetrated people's minds, influenced and changed people's thoughts and behaviors, and on the other hand, provided endless impetus for social activists like Kang Youwei, Liang Qichao, Huang Zunxian, and later Lu Xun. Yan Fu's translations are known as "Eight masterpieces of Yan".

According to Kang Youwei, the Chinese scholar and prominent political thinker, of the famous translators of Late Qing Dynasty, only Lin Shu (1852-1924) could be juxtaposed with Yan Fu in terms of achievements and influence of translation. Lin Shu, also known as Lin Qinnan, born in Fujian province, did not understand English but became "the first master of literary translation in modern China" (Zhu, 2015), also known as "The Grandmaster of Translation" (Fang, 2005: 24). Although Lin Shu embarked on translation career by accident, as a reformist, after experiencing events such as the Sino-Japanese War, Gongche Shangshu the political movement in 1895, and personal frustrations, he had always "hoped that he could spread the advanced ideas and culture of the Western countries with his words" (Zhu, 2015), which is also his original intention of and purpose for being engaged in translation. After his first success in translating, through cooperation with Wang Shouchang in 1898, the "La Traviata de Paris", which was published by the Commercial Press, he successively translated and published a series of more than 180 books by working with a lot others, including "Tom Uncle's Cabin", "David Copperfield", "Aesop's Fables", etc. and what's more, he "instilled readers with his patriotic thoughts of saving the country from the edge of collapse to stimulate their passion for fighting against imperialism" in forms of prefaces, comments, and phrases" (Zhu \& Zhang, 2009).

Lin Shu himself also believes that the purpose of translation is to "hope that the entire Chinese people could work hard to avoid the fate of being enslaved"; and in particular, the introduction and translation of "Tom Uncle's Cabin", "is a great help in cheering up for patriotism and self-reliance" (Fang, 2015:28). His achievements in translation and his influence on the later generations had indirectly helped him realize his ideals and ambitions. 
Translation, like other forms of human behavior, is a purposeful action, and the translation activity itself is part of the overall action (Flynn, 2004). As per individual translators, Liang Qichao (1873-1929) is the only one who directly took advantage of translation to serve his actions and integrated the two aspects tightly. Liang Qichao set up the "Datong Translation House" in 1897 as mentioned above, with the tenet of "primarily translating the books on reforms of other countries, and everything that are related to the future reforms in order to prepare for today's legal practice; translating the constitutional books to establish the basis of the country governance; translating rules and regulations for guidelines in dealing with various affairs; translating business books to promote Chinese business studies and restoring the rights of the people" (Fang, 2005: 3). With this clear and eminent purpose, Liang Qichao first translated the "Isles of Greece" by British poet Byron, because the poem is "passionate and enthusiastic enough to make exciting reading," and therefore "being eager to utilize his verses to inspire Chinese people's morale, to be bold enough to declare war on the reactionary and feudal forces ", and at the same time paying attention to preserve and convey such an overwhelming momentum in translation, striving to achieve the "primary aim of retaining its spirit" (Fang, 2005: 10).

\subsection{Summary}

It can be seen that according to the selection, implementation, content, and strategy of the translation activities in the late Qing Dynasty, this wave of translation has taken the following lines: from the religious texts mainly based on the Bible, to scientific and technological literatures such as photoacoustic and agricultural medicine, to politics, economy, society, history, and magnificent literary works. The majority of the translators were from both China and western countries, from government-affiliated agencies to civil institutions, in the form of close cooperation between native Chinese and foreigners.

The first Jesuits arrived in China in 1583 and settled down. They learned Chinese to understand local culture for the purpose of spreading Christianity and developing disciples. Throughout the 17th and 18th centuries, a total of approximately 900 Jesuits preached in China (Waley-Cohen, 1999: 62-63). In order to obtain the trust of the people, the missionaries also disseminated practical scientific knowledge such as medicine and agriculture. In this way, some missionaries, especially those Jesuits who had settled in China for a long or even life time, gradually mastered Chinese; while the Chinese who had a close relationship with the missionaries also acquired foreign languages such as Portuguese and English. This situation had laid a foundation and convenience for the later increasingly frequent business activities. Therefore, the translation activities required for communication between China and western countries during the late Qing Dynasty did not come from scratch.

After the Opium War, the Qing government and Western powers entered full confrontation and conflicts in politics, commerce, law, and culture. Western governments needed assistance from Chinese people in dealing with Qing government and missionaries also needed local people who knew foreign languages in spreading their creed especially the translation of scientific works. Similarly, the Qing government would consult foreign professionals who were sympathetic with China in negotiating Western governments. Therefore, there were Chinese experts in Western publishing and translation agencies just as the case that western missionaries were also employed by the translation departments of Tongwenguan and the Jiangnan Arsenal, forming a close cooperative relationship.

At the government level of Qing Dynasty, from the establishment of the Ministry of General Foreign Affairs in 1861 to the 1870s, from the reformists such as Yi Xin and Wen Xiang at the Central Government to local officials like Zeng Guofan, Li Hongzhang, and Zuo Zongtang, they assumed an open mind, boldly employing Catholic missionaries to carry on the training of foreign language talents and the introduction of Western books on science and technology. In addition to purchasing machines directly from the West, Zeng Guofan and Li Hongzhang claimed that China must also learn machine manufacturing, and therefore regarded translation as an important way to acquire Western modern manufacturing technology and engineering mathematics.

In the 1850s, the London Missionary Association (LMS) hired Xu Shou, Li Shanlan, and Hua Yifang to work with Wylie and MacGowan, etc. in Inkstone Press for translation tasks. About a decade later, in the 1860s, the Jiangnan Arsenal again hired Wylie and MacGowan to do translation assigned by Qing government with $\mathrm{Xu}$, Li and Hua in the Translation Department (Elman, 2005: 356). William A. P. Martin first served as a Chinese interpreter for the US Ambassador to China, William Reed, and later succeeded John Fryer as English language teacher of Tongwenguan. Through the reform of the personnel training program and curriculum, Martin has, on the one hand, "trained the first generation of various talents for the country including politicians, diplomats, translators, scientific and technological talents with Western modern science," and on the other hand, the books on Western learning that he introduced and translated have "not only provided important knowledge and ideological resources for the Westernization Movement, but also had a profound influence on the society of the late Qing Dynasty" (Zhang Meiping, 2016). 


\section{Facilitating Role of Translation in Social Reforms of Late Qing Period}

As mentioned earlier, Skopos theory holds that translation as a purposeful activity can lead to or generate a new event or situation. For example, a factory imports a set of mechanical equipment from abroad. After the instructions being translated into Chinese, engineers can follow the instructions and know how to operate, repair, or replace parts and this is a new situation created by translation. When we read Mr. Wang Zuoliang's translation of Bacon's "Of Studies", its beautiful rhythm enables us to enjoy the pleasure, with its accurate expressions deepening our understanding of the importance of reading. This is the catalysis and promotion of ideas triggered by translation. Of course, for the huge empire like the Qing Dynasty, one or two translators or translations could by no means play a catalytic role. Even the large number of translations such as those works on Western science and technology between 1840 and 1895 completed by so many Chinese and foreign translators had, in Wright's view, only directly affected a small number of intellectual elite. Therefore, this endeavor was a failure (Wright, 1998: 672). Coincidentally, John Fryer, who himself played an important role in this wave of translations and hoped to "fully educate Chinese people" through translation, also believed, after the Sino-Japanese War, that the fierce defeat of the Qing government proved all of their efforts since 1865 had been in vain (Elman, 2005: 394).

Obviously, both of them have overestimated the role of translation, especially for Fryer, the view of whom actually reflects his disappointment after making so great efforts with enthusiasm in this aspect. However, we cannot deny the facilitating role of translation in the social transformation in late Qing Dynasty. As far as China's social structure was concerned, the vast majority of farmers did not have the opportunity to receive formal education. Western learning on science and technology, politics and economy, as well as humanistic thoughts were usually limited to intellectual elites and scholar-bureaucrats, while the reasons for China defeat in the Sino-Japanese War were also extremely complicated, so it cannot be simply concluded that translation activities for more than half a century were a failure. One of the hallmarks of human intelligence is the ability to create and reorganize the concept of the world to adapt to changing goals and circumstances, and thus the language we use influences our perception of the world around us (Boroditsky, 2011). Translation activities, through the dissemination of advanced knowledge and key concepts, such as "self-improvement," "democracy, "survival of the fittest," and "natural selection," gradually change people's thinking and understanding, and then influence people's actions and behavior. From "moistening things silently" to the trickle, then to the surging waves, translation plays the role of "crushing dry weeds and smashing rotten wood".

After the Opium War, the Qing government suffered from internal and external difficulties, with society in a state of turmoil, people living on the edge of starvation. At this critical moment of life and death of Qing Dynasty, the Western powers were casting covetous eyes on it, whereas upright Chinese with high ideals were seeking changes. Under such confrontation and conflict, translation activities were carried out through both unilateral efforts and mutual cooperation, characterized by urgency, purposefulness, and practicality. From the perspective of Skopos theory, this urgent situation determines the strong purpose of the translation activity and the diversification of purposes, which is mainly manifested in the different purposes on the side of China and on the side of western countries. For example, the foreigners were involved in translation out of missionary, business and political purposes, with a small number in the hope of bringing advanced knowledge and concepts to practically help China to become rich and powerful. In the $1860 \mathrm{~s}$, missionaries and western government officials had started to translate and introduce Western international laws for the purpose of "popularizing law" to the Qing government in order to better communicate with it. To that end, they first introduced and translated "Rights of Diplomatic Envoy" from the "Elements of International Law" "for the reference of the Ministry of General Foreign Affairs, so as to persuade Qing Government to send representatives abroad" (He, 2001).

There were also different purposes on China side. Some government officials like Lin Zexu, wanted to be better informed of the situation of western countries, so as to have a clearer picture in dealing with them, either for struggling for justified rights, or for resisting unequal requirements from the western powers based on an understanding of international practices. In this way, the Chinese people could not only open their eyes to the outside world, but know better how to maintain their rule. The translation of parts of "Elements of International Law" as delegated by Lin Zexun during his stay in Guangzhou as the Imperial Envoy to ban the Opium, has enabled "the Chinese, especially its advanced intellectuals, not only to acquire the knowledge and concepts of international law such as respecting national sovereignty, equality of countries, and non-interference with each other's internal affairs, but also to learn about the core content of Western legal culture, namely the concept of the rule of law. It was based on such knowledge that the Qing government successfully resolved the "Putan Dagukou ship incident" (ibid.). Some progressive intellectuals or social activists, who, after learning about Western advanced concepts, had more clearly realized the corruption and backwardness of the Qing government by comparison, were eager to awaken the Chinese people through translation, for the sake of overthrowing this institution and replace it with a new system. 
The vigorous translation activities promoted by diversified purposes, have invariably made people aware of the outside world, realizing that China is not the center of the world and should not be arrogant. On the other hand, the ideas of democracy, self-improvement, etc. have also deeply penetrated the minds of people with the publication of newspaper and books. In short, the facilitating role of the translation activities during the late Qing Dynasty of China is mainly reflected in the following three aspects:

\subsection{Enlightening People's Mind through Communication between East and West}

In 1832, American missionary E. C. Bridgman (1801-1861) began publishing the monthly "The Chinese Repository" in Guangzhou, mainly introducing Chinese history, culture, and current affairs to Protestant missionaries working in Asia. As a window of western countries, especially Britain and the United States to understand China situation, this publication continued until 1851, leaving precious historical data for contemporary study of Qing Dynasty. After the establishment of "the society for the diffusion of useful knowledge in China" in 1834, it had been committed to translating and printing books on Western history, geography, nature, medicine, and machinery in China. In 1838 Parker formed a medical missionary agency. From the end of the 1840s to the early $1850 \mathrm{~s}$, MacGowan published the Philosophical Almanac in 1851 to introduce electricity and electrotherapy. As a British medical missionary, Hobson translated a series of works on medical and natural sciences with the help of several Chinese scholars, and compiled it into a new book Bowuxinbian, providing important information for popularizing medical knowledge. Later, J.G. Kerr (1824-1890), J. Dudgeon (1837-1901) and Fryer successively translated some new books, and had completed the translation and publication of twenty-four medical works by 1896, thus laying the foundation for the transformation of Chinese traditional medicine to modern medicine.

Also in the 1850s, Wylie and Chinese experts Li Shanlan, etc. who were employed by Inkstone Press, translated a series of Western science books and introduced them to Chinese readers through the new publication "Shanghai Serial". They also translated a lot of mathematics and scientific literature, such as "Algebra", "Mathematics Enlightenment" and so on, introducing basic scientific knowledge such as modern mathematics and calculus to China. In addition to this, William Martin's translation of the "Natural Philosophy" is the earliest widely used science education textbook in church schools. Joseph Edkins's "Outline for New Learning of Natural Philosophy" introduced the history of the development of modern science and was published in the "The Church News" in 1872. He also translated "A Manual of Political Economy" by Henry Fawcett into Chinese together with his colleagues.

From the perspective of the Qing government, of the books translated under the supervision of John Fryer, fifty-seven books were on natural sciences, forty-eight on applied sciences, and eighteen on mechanical manufacturing. At the end of the 1870s, Fryer and his colleagues focused on the translating of a series of introductory texts to lay a good foundation for students to carry out more advanced science and technology studies, such as "Gezhi Xuzhi", "Gezhi Tushuo", and "Gezhi Enlightenment" (Elman, 2005: 321-322). In addition, Edkins translated Huxley's "Science Primers Introductory". The 1886 edition of the 16-volume "Science for Beginnings" was re-published in 1896 with the new title of "Enlightenment for Western Learning". He also worked with Li Shanlan and Williamson to complete the translation of "Botany". In short, the terms created by Chinese and foreign translators in more than half a century's translation activities have become the cornerstone of modern Chinese science, and have also laid the foundation for the rapid development of Chinese science and technology in the 20th century (Wright, 1998: 672-673; Elman, 2005: 414-415).

Literature is a window for understanding society, and Lin Shu is "a pioneer who translates Western literature into China" (Lin, 2002). Through his translated novels, "Chinese people have been able to get a comprehensive view of Western customs and practices, social issues, literary trends, moral values, family relationships, and a brightly shining literary world"(Hsu, 1983). From religions during the initial stage to the science of sound and photonics, to medicine, geography, economics, politics, and even literature, the advanced scientific knowledge in the West was introduced into China through publication of books and distribution of newspapers, enabling some Chinese especially the upper class officials and intellectual elites to see the outside world firstly, and to realize the gaps between China and the Western countries. At the same time, the translation of books on Chinese culture into foreign languages has also allowed some Westerners to understand the long history and culture of China. This interaction has played an active role in enlightening people's wisdom and promoting communication between China and the West.

\subsection{Absorbing Western Learning for Self-Improvement}

In the 1830s, the German missionary K. F. A. Gutzlaff (1803-1851), who was active in "The Society for the Diffusion of Useful Knowledge in China", edited and printed the "Eastern-Western Monthly Magazine". This magazine had become the major source for Lin Zexu to collect and translate information on Western powers during his term as the Imperial Envoy to Guangzhou to ban opium. The "Sizhouzhi" compiled under the administration of 
Lin Zexu contained some of the contents of the magazine, which then became the source of Wei Yuan's "Map of the Sea States".

Yan Fu's translation of "Evolution of Species" has played a profound and enlightening role in facilitating and promoting social reforms in late Qing Dynasty, which was expressed in the words of the Japanese scholar, Inaba Junshan, who said that "Yanfu's translation of 'Evolution of Species'by Darwin is the source of thought for Chinese modern innovations that began in 1895" (Fang, 2005: 18). Through Yan Fu's eight translation masterpieces, Chinese people who had long been isolated from the outside world, with minds being locked, "have gained direct access to the exciting concepts such as evolution, free trade, and sociological principles, as well as Western forms of government organization" (Lin, 2002).

In late Qing Dynasty since Lin Zexu period, under the ideology of "learning from the Barbarians to counterattack them", the primary task of translation agencies was to translate the works on western machine manufacturing in order to achieve independent design and manufacture as soon as possible, thus achieving the goal of "making use of stones from other mountains to polish jades" as well as self-reliance and self-improvement. For example, the translation of "Elements of International Law" by William Martin has "not only introduced Western international law, especially the sovereign consciousness ... but also the legal system and concepts of western bourgeois... and thus laying the political, legal and ideological foundation for the vigorous anti-imperialist and anti-feudal movements such as the Reform Movement of 1898 led by Kang Youwei and Liang Qichao and the Chinese Revolution of 1911 (He, 2001).

\subsection{Reforming and Innovating with Overwhelming Strength}

After various types of translation activities in natural science and social science, which had experienced vigorous period and ups and downs for decades, it was not until the end of the 19th century that literary translations based on British and American novels were finally unveiled. The "La Traviate de Paris", "Uncle Tom's Cabin"and "David Copperfield"translated by Lin Shu were the most popular. Liang Qichao believes that, unlike other types of genres, novels can achieve "unbelievable power to control humanity through the four forces of 'smoking,' 'soaking,' 'thorning,' and 'raising." The reasons lie in the fact that "as emotional beings, people are universally much easily absorbed by the plots of the novels, thus becoming sympathetic with the characters within the novel, and this is the result of psychological effect beyond the control of human being"(Liang, 1902). In addition, based on his own experience in Japan, where he personally witnessed social changes in Japan after the Meiji Restoration, he strongly advocated the translation of Japanese political novels because the fictional revolution could not only "improve group governance" but also "reform people's thought", and he considered his translation of "The Adventures of a Wonderful Lady" and Zhou Kui's translation of "Jing Guo Mei Tan" to be "the most effective in penetrating innovative ideas into people's brains" (Fang, 2005: 7).

In addition, Sheldon H. Lu also pointed out that "reformists, social activists, scholars, and critics all believe that the literary form of fiction is of great value in moral education, ideology, and social influence" (Lu, 2003: 746). From this point of view, the hundreds of novels translated by the translators such as Lin Shu in the period of late Qing dynasty have made great contributions in transforming the spirit and promoting the ideas of people at that time.

"At the end of the nineteenth century, two translation books awakened the intellectual world and promoted the development of history.... Some people say that the rise of revolutionary democracy and the victory of the Chinese Revolution of 1911 in late Qing Dynasty should be attributed to the "Evolution of Species" and "La Traviata de Paris". Although this statement seems a bit exaggeration, it is not too much excessive in saying that the two books had really played a significant role in enlightening people's minds" (Jiang Xijin "About Lin Qinnan", cited from Fang Huawen, 2015: 25). The goal of Guangxuehui, established on the basis of "The Society for the Diffusion of Useful Knowledge in China" was "to introduce modern science and liberal thought as a means to overthrow ancient superstitions and to prepare the way for inevitable innovations in China" (Elman, 2005: 323). Through translation of books and circulation of newspapers, the organization had gradually grown to be the largest missionary publishing institution in China at the time. Its "Church News", "Chinese and Western Church Newspaper" and "Datong News" published speeches by Chinese and Western reformists and greatly pushed forward the Reform Movement of 1898 and The Chinese Revolution of 1911.

\section{Conclusion}

Unlike the previous two waves of translation in the history of China, the translation climax of late Qing Dynasty was a cross-cultural communication between China and western powers at a time when it was being tortured by internal 
turmoil and external infringement, with its rule swinging back and forth unstably as the result of fierce confrontation and conflict between the Chinese and Western cultures. The Skopos theory holds that translation is a purposeful activity. The Western translators as mentioned in this article are predominantly missionaries who conducted translation for religious as well as political and business purposes. The Chinese local translators, most of whom were employed by official departments of the government, undertook translation in face of Western invasion for the purpose of learning about the western thoughts, cultures and behaviors so as to better deal with them. The translation of this period ranged from religious texts like the Bible, to acoustics and optics, agriculture, medicine, politics, economy, and finally to novel and poetry, showing the characteristics of urgency and practicality, with the trend going from spirit to material and to spirit again.

Regardless of the subject matter, translation has intentionally or unintentionally enabled the Chinese people to learn about the world beyond the scope of their cognition at that time and changed their understanding of nature, society, and themselves, especially in the political, economic, legal, and humanities fields. The introduction of brand-new concepts allowed advanced intellectuals and social activists to start rethinking social structures and forms of government organization. D. Robinson posits that in order for translation texts to play an effective role in political activities, text users must make extensive publicity to make the text content deeply rooted (Robinson, 1997: 108). Tymoczko pointed out that most translators, when undertaking translation tasks, believe that "the texts they produce will benefit humanity or impact positively upon the receptor culture in ways that are broadly ideological" (Tymoczko, 2000). During the translation climax of the period of late Qing Dynasty, translators took part in social changes more actively than ever before and became the main driving force for the advancement of Western learning in China. They have not only promoted social transformation, but also prepared ideas and talents for the Revolution of 1911 with new energy and vitality generated in their translations.

\section{References}

Boroditsky, Lera. (2011). How Language Shapes Thought. NATURE PUBLISHING GROUP, NEW YORK. https://doi.org/10.1038/scientificamerican

Chen, Sihe. (2017). Great Contributions of Yan Fu and Lin Shu: Preface to the Translation of "La Traviata de Paris" and "Evolution of Species". Wen Hui Newspaper (April 8).

Chesneaux, J., Bastid, M., Bergère, M., \& Destenay, A. (1977). China from the Opium Wars to the 1911 Revolution. Harvester Press, Hassocks.

Elman, B. A. (2005). On Their Own Terms. Harvard University Press: Boston. https://doi.org/10.4159/9780674036475

Fang, Huawen. (2005). History of Translation in the $20^{\text {th }}$-Century China. North-West University Press: Xi'an.

Flynn, P. (2004). Skopos theory: An ethnographic enquiry. Perspectives, 12(4), 270-285. https://doi.org/10.1080/0907676X.2004.9961507.

He, Qinhua. (2001). "Elements of International Law" and International Law of Late Qing Dynasty. Chinese Journal of Law, 5, 137-148.

Hsü, I. C. Y. (1983). The Rise of Modern China (3rd ed.). Oxford University Press, Oxford: New York.

Liang, Qichao. (1902). Towards the Relationship between Novels and Group Governance. New Novel, First Issue.

Lin, Kenan. (2002). Translation as a Catalyst for Social Change in China. In Tymoczko, M., \& Gentzler, E. (ed.), Translation and Power. University of Massachusetts Press, Amherst.

Liu, Li \& Lan, Xingwei. (2015). Influence of Inkstone Press on Translation Activities in Modern History of China. Lan Tai World, March, 115-116.

Lu, S. H. (2003; 2004). Waking to modernity: The classical tale in late-Qing China. New Literary History, 34(4), 745-760. https://doi.org/10.1353/nlh.2004.0001

Nord, C. (2002). Manipulation and loyalty in functional translation. Current Writing: Text and Reception in Southern Africa, 14(2), 32-44(2002). https://doi.org/10.1080/1013929X.2002.9678123.

Nord, C. (2014). Translating as a purposeful activity: Functionalist approaches explained. Routledge: London \& New York. https://doi.org/10.4324/9781315760506

Pym, A. (2010). Exploring translation theories (2nd ed.). Routledge: London \& New York. 
Robinson, D. (1997). Translation and Empire: Postcolonial Theories Explained. St. Jerome, Manchester. https://doi.org/10.1080/13556509.2000.10799054

Tymoczko, M. (2000). Translation and Political Engagement: Activism, social change and the role of translation in geopolitical shifts. Translator: Studies in Intercultural Communication, 6(1), $23-47$. https://doi.org/10.1080/13556509.2000.10799054

Vermeer, Hans J. (2000). Skopos and Commission in Translational Action. In: Venuti, Lawrence (ed.), The Translation Studies Reader. Routledge, London \& New York.

Waley-Cohen, J. (1999). The Sextants of Beijing: Global Currents in Chinese History. W. W. Norton \& Company, New York: London.

Zhang, Meiping. (2010). Translation is the Fundamental Factor for Manufacturing: Translation Activities of Jiang'nan Arsenal and Their Influence. Journal of Chinese Translators, 6, 38-42.

Zhang, Meiping. (2016). William Martin and Teaching of Translation in Imperial Tongwenguan. Journal of Shu Ren University, 2.

Zhu, Yaoxian \& Zhang, Xiangyu. (2009). Translation of Lin Shu: Politics for Soul and Translation for Industry. Journal of Zhengzhou University (Philosophy and Social Science), 42(05), 134-137.

Zhu, Yu. (2008). Translation of Lin Shu and His Times. Journal of Modern Chinese Literary Studies, $5,70-77$. 